\title{
Reversible Deposition and Dissolution of Magnesium from Imidazolium-Based Ionic Liquids
}

\author{
QingSong Zhao, Yanna NuLi, Tuerxun Nasiman, Jun Yang, and JiuLin Wang \\ Department of Chemical Engineering, Shanghai Jiao Tong University, Shanghai 200240, China \\ Correspondence should be addressed to Yanna NuLi, nlyn@sjtu.edu.cn
}

Received 19 December 2011; Revised 10 February 2012; Accepted 23 February 2012

Academic Editor: Sherif Zein El Abedin

Copyright (C) 2012 QingSong Zhao et al. This is an open access article distributed under the Creative Commons Attribution License, which permits unrestricted use, distribution, and reproduction in any medium, provided the original work is properly cited.

\begin{abstract}
The electrochemical performance of six imidazolium cation-based ionic liquids (ILs) containing $0.3 \mathrm{~mol} \mathrm{~L}^{-1} \mathrm{Mg}\left(\mathrm{CF}_{3} \mathrm{SO}_{3}\right)_{2}$ as the electrolytes for magnesium deposition-dissolution was examined by cyclic voltammogramms and constant current dischargecharge techniques. Scanning electron microscopy and energy dispersive X-ray spectroscopy measurements were conducted to characterize the morphologies and components of the deposits. The cathodic satiability of imidazolium cations can be improved by increasing the length of alkyls at the 1-position and introducing methyl group at the 2-position of the imidazolium cations. A reversible magnesium deposition-dissolution can be achieved at room temperature. After adding appreciate amount of tetrahydrofuran (THF) organic solvent, the conductivity and the peak currents for $\mathrm{Mg}$ deposition and dissolution can be significantly improved. The potential polarization of deposition-dissolution process is decreased using $\mathrm{Mg}$ powder electrode.
\end{abstract}

\section{Introduction}

Increasing depletion of fossil resources, serious industrial pollution, and ecological destruction have cried for low-cost and high energy density rechargeable batteries for electric vehicles, load leveling, and storage of energy from renewable sources [1]. Due to higher theoretical capacity $(2205 \mathrm{mAh} / \mathrm{g})$, higher negative potential (about $-2 \mathrm{~V}$ versus standard hydrogen electrode in aprotic solutions), low cost, safe to handle and environmentally friendly nature, metallic magnesium is an attractive candidate for the active material of high energy density batteries [2-4]. But in many nonaqueous solutions, a reversible process of electrochemical deposition and dissolution of magnesium is hard to achieve because of the formation of compact passive film [5]. It is known that electrochemical $\mathrm{Mg}$ deposition is impossible from solutions containing simple ionic $\mathrm{Mg}$ salts (such as $\mathrm{MgCl}_{2}$, $\mathrm{Mg}\left(\mathrm{ClO}_{4}\right)_{2}$, etc.) in commonly used aprotic solvents (such as alkyl carbonates, esters, and acetonitrile) [6, 7]. However, magnesium can be reversibly deposited electrochemically in the systems without the passivating phenomena, such as ethereal solutions of Grignard reagents $(\mathrm{RMgX}, \mathrm{R}=$ alkyl, aryl groups; $\mathrm{X}=$ halide: $\mathrm{Cl}, \mathrm{Br}$ ) [7-10], amidomagnesium halides [11, 12], $\mathrm{Mg}\left(\mathrm{BR}_{2} \mathrm{R}_{2}^{\prime}\right)_{2}\left(\mathrm{R}=\right.$ alkyl and $\mathrm{R}^{\prime}=$ aryl group $)$ $[2,11], \operatorname{Mg}\left(\mathrm{AX}_{4-n} \mathrm{R}_{n^{\prime}} \mathrm{R}_{n^{\prime \prime}}^{\prime}\right)_{2}\left(\mathrm{~A}=\mathrm{Al}, \mathrm{B} ; \mathrm{X}=\mathrm{Cl}, \mathrm{Br} ; \mathrm{R}, \mathrm{R}^{\prime}=\right.$ alkyl or aryl groups, and $\left.n^{\prime}+n^{\prime \prime}=n\right)[13,14]$, and $\mathrm{PhMgCl}_{-\mathrm{AlCl}_{3}}$ [15]. However, those electrolyte systems still suffer from the problems of safety and reliability due to the flammability and high vapor pressure of the ethereal solvents.

As we know, ionic liquids (ILs) have been widely researched and applied in organic synthesis, catalysis, separations, and electrochemistry owing to the superior performance such as nonflammability, wide liquid-phase range, low vapour pressure, lack of volatility, wide electrochemical window, and great thermal and electrochemical stability [16-20]. ILs were used as electrolytes for electrochemically reversible deposition and dissolution of lithium $[21,22]$. In particular, ILs have been regarded as attractive candidates for lithium-battery electrolyte [23-25]. We first reported the electrodeposition of magnesium in imidazolium-based and piperidine-based ionic liquids [26-29]. Cheek et al. studied the electrodeposition of magnesium in imidazolium-based ILs and pyrrole-based ILs containing a Grignard reagent or several inorganic magnesium salts [30]. Recently, Morita et al. [31, 32] reported Mg electrodeposition from the electrolyte consisted of quaternary ammonium-based ILs with 


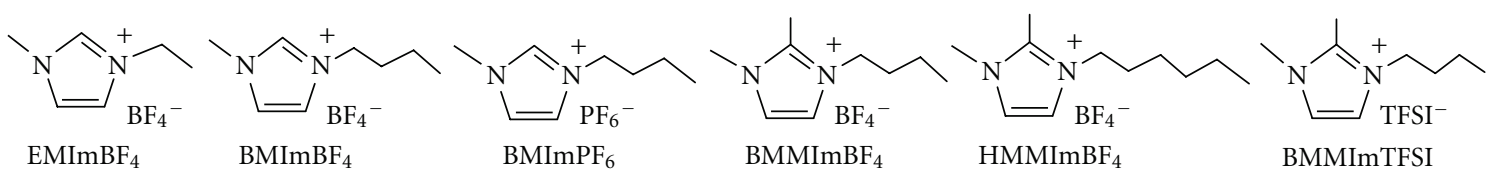

FIGURE 1: Chemical structures of the imidazolium-based ILs used in this work.

Grignard reagents or simple $\mathrm{Mg}$ salt, and they also synthesized a series of imidazolium-based ILs and examined the electrodeposition of magnesium from the solution mixed the ILs with a Grignard reagent [33].

In this paper, we systematically studied the relation between the chemical structure of imidazolium-based ILs containing $\mathrm{Mg}\left(\mathrm{CF}_{3} \mathrm{SO}_{3}\right)_{2}$ and the ionic conductivity, electrochemical window, and $\mathrm{Mg}$ deposition and dissolution. Furthermore, tetrahydrofuran (THF) as an additive was added in the electrolytes to improve the electrochemical performance of the electrolytes.

\section{Experimental}

2.1. Preparation of Electrolytes. 1-Ethyl-3-methylimidazolium tetrafluoroborate $\left(\mathrm{EMImBF}_{4},>99.0 \%\right)$, 1-butyl-3-methylimidazolium tetrafluoroborate $\left(\mathrm{BMImBF}_{4},>99.0 \%\right)$, 1-butyl-3-methylimidazolium hexafluorophosphate $\left(\mathrm{BMImPF}_{6},>99.0 \%\right)$, 1-butyl-2,3-dimethylimidazolium tetrafluoroborate (BMMImBF $4,>99.0 \%)$, 1-hexyl-2,3-dimethylimidazolium tetrafluoroborate $\left(\mathrm{HMMImBF}_{4},>99.0 \%\right)$, 1-butyl -2,3-dimethylimidazolium bis((trifluoromethyl)sulfonyl) imide (BMMImTFSI, >99.0\%) were purchased from Center for Green Chemistry and Catalysis (LICP, CAS, China) and used as received. Figure 1 shows the chemical structure of these imidazolium-based ILs. $\mathrm{Mg}\left(\mathrm{CF}_{3} \mathrm{SO}_{3}\right)_{2}$ (Alfa Aesar) was stored under an argon atmosphere and used without further treatment. Tetrahydrofuran (Aladdin, 99.9\%) was redistilled to receive lower water content. $0.3 \mathrm{~mol} \mathrm{~L}^{-1}$ solutions were prepared by adding appropriate amount of $\mathrm{Mg}\left(\mathrm{CF}_{3} \mathrm{SO}_{3}\right)_{2}$ to imidazolium-based ILs in an airtight flask inside an argon-filled glove box (Mbraun, Unilab, Germany) and stirring the mixtures inside the box at room temperature for about $12 \mathrm{~h}$. Then, appropriate amount of THF with different volume ratio was added and stirred about several hours.

2.2. Measurement Procedures and Apparatus. The specific conductivity of the solutions was measured using an FE30 conductivity meter and the InLab 710 conductivity measuring cell (Mettler Toledo, Switzerland). FTIR spectroscopy of the solutions was conducted with Paragon 1000 (Perkin Elmer, Inc., USA) at $4000-450 \mathrm{~cm}^{-1}$, resolution $0.1 \mathrm{~cm}^{-1}$. The samples were prepared by evenly spreading solution on $\mathrm{KBr}$ disc.

Cyclic voltammograms (CVs) of three-electrode cells were conducted in the argon-filled glove box at room temperature using an electrochemical instrument of CHI604A Electrochemical Workstation (Shanghai, China). The working electrode was Pt disk (geometric area $=3.14 \times 10^{-2} \mathrm{~cm}^{2}$ ), and magnesium ribbon ( $1 \mathrm{~mm}$ diameter) (Aldrich) served as
TABle 1: Conductivity and electrochemical window of the imidazolium-based ILs used in this work.

\begin{tabular}{lcc}
\hline Ionic liquids & $\begin{array}{c}\text { Conductivity/mS } \\
\mathrm{cm}^{-1}\left(25^{\circ} \mathrm{C}\right)\end{array}$ & $\begin{array}{c}\text { Electrochemical window of } \\
\text { ionic liquids on } \mathrm{Pt} \\
\text { electrode/V versus } \mathrm{Mg}\end{array}$ \\
\hline $\mathrm{EMImBF}_{4}$ & 14.46 & $0.3-3.0$ \\
$\mathrm{BMImBF}_{4}$ & 3.36 & $-0.4-3.0$ \\
$\mathrm{BMImPF}_{6}$ & 1.33 & $-0.6-3.5$ \\
$\mathrm{HMMImBF}_{4}$ & 0.43 & $-1.2-3.2$ \\
$\mathrm{BMMImTFSI}_{\mathrm{BMMImBF}}$ & 1.94 & $-1.0-3.2$ \\
$\mathrm{BMM}_{4}$ & $2.05\left(40^{\circ} \mathrm{C}\right)$ & $-0.8-3.2$ \\
\hline
\end{tabular}

counter and reference electrodes. All of the electrodes were polished before use.

Electrochemical magnesium deposition-dissolution cycles were examined with CR2025 coin-type cells. Copper foil $(\Phi 12 \mathrm{~mm})$ was used as a working electrode (substrate) for the deposition and dissolution of magnesium. Magnesium strip or a mixture of $90 \mathrm{wt} . \% \mathrm{Mg}$ powder (99\%, Sinopharm Chemical Reagent Co., Ltd.) ball-milled $350 \mathrm{rmp}$ for $10 \mathrm{~h}$ and sieved (300 mesh), 3 wt.\% carbon black, and 7 wt.\% polytetrafluoroethylene (Aldrich) binder pressed on $\mathrm{Cu}$ foil as a counter electrode. Glass fiber membrane was used as a separator. The cells were assembled in the glove box. Magnesium was deposited onto the substrate for fixed periods of $30 \mathrm{~min}$ followed by stripping to a fixed potential limit of $0.8 \mathrm{~V}$ versus $\mathrm{Mg}$ at a constant current density of $0.1 \mathrm{~mA} \mathrm{~cm}^{-2}$. There was a $30 \mathrm{~s}$ rest between deposition and dissolution. The magnesium deposition and dissolution on the substrate was referred as the discharge and charge process, respectively. The time of charge divided by the time of discharge was defined as the deposition-dissolution efficiency.

The surface morphology and element analysis of the electrodeposits were examined on a JEOL JSM-6460 scanning electron microscope (SEM) equipped with an energy dispersive X-ray spectroscopy (EDS). The samples were deposited for $10 \mathrm{~h}$ on copper substrate at $0.05 \mathrm{~mA} \mathrm{~cm}^{-2}$ and washed carefully with drying THF solvent to remove soluble residue in the glove box. Then, the samples were transferred out of the box and kept carefully without exposure to the atmosphere.

\section{Results and Discussion}

The ionic conductivity and the electrochemical window of several imidazolium-based ILs are summarized in Table 1. The conductivity tends to decrease with increasing the length of alkyls at the 1-position and introducing methyl group 
TABLE 2: Conductivity of the solutions dissolving $0.3 \mathrm{~mol} \mathrm{~L}^{-1} \mathrm{Mg}\left(\mathrm{CF}_{3} \mathrm{SO}_{3}\right)_{2}$ in ILs without or with THF by different volume ratios for ILs and THF.

\begin{tabular}{|c|c|c|c|c|c|c|}
\hline Solutions without THF & $\mathrm{BMImBF}_{4}$ & $\mathrm{BMImPF}_{6}$ & $\mathrm{HMMImBF}_{4}$ & BMMImTFSI & $\mathrm{BMMImBF}_{4}$ & \\
\hline Conductivity $/ \mathrm{mS} \mathrm{cm}^{-1}\left(25^{\circ} \mathrm{C}\right)$ & 3.08 & 1.31 & 0.32 & 1.79 & $1.18\left(40^{\circ} \mathrm{C}\right)$ & \\
\hline Solutions with THF & $\begin{array}{c}\mathrm{BMImBF}_{4} \\
(6: 1)\end{array}$ & $\begin{array}{c}\mathrm{BMImBF}_{4} \\
(3: 1)\end{array}$ & $\begin{array}{c}\mathrm{BMImBF}_{4} \\
(1: 1)\end{array}$ & $\begin{array}{c}\mathrm{BMMImBF}_{4} \\
(6: 1)\end{array}$ & $\begin{array}{c}\mathrm{BMMImBF}_{4} \\
(3: 1)\end{array}$ & $\begin{array}{c}\mathrm{BMMImBF}_{4} \\
(1: 1)\end{array}$ \\
\hline Conductivity $/ \mathrm{mS} \mathrm{cm}^{-1}\left(25^{\circ} \mathrm{C}\right)$ & 5.72 & 8.03 & 9.33 & 1.97 & 3.65 & 5.56 \\
\hline
\end{tabular}

at the 2-position of the imidazolium ring. The cathodic and anodic limits of the electrochemical window depend on the anions and cations of the ILs, respectively. The cation stability is as follows: $\mathrm{EMIm}^{+}<\mathrm{BMIm}^{+}<\mathrm{BMMIm}^{+}<$ $\mathrm{HMMIm}^{+}$. Increasing the length of alkyls at the 1-position of the imidazolium ring seems to lead to a lower potential for the cathodic limit. Furthermore, the cathodic stability is improved by introducing methyl group at the 2-position because the proton at 2-position has stronger reactivity. The result suggests that the reduction potential of $\mathrm{EMImBF}_{4}$ is above $0 \mathrm{~V}$ versus $\mathrm{Mg}$, and EMIm-based ILs cannot be used for magnesium deposition electrolyte. On the other hand, the stability of different anions is as follows: $\mathrm{BF}_{4}{ }^{-}<\mathrm{TFSI}^{-}<$ $\mathrm{PF}_{6}{ }^{-}$. The anodic stability tends to improve using TFSI $^{-}$and $\mathrm{PF}_{6}{ }^{-}$anions. However, the reversible deposition-dissolution of magnesium cannot be obtained in the solutions of $\mathrm{BMImPF}_{6}$ or BMMImTFSI containing $\mathrm{Mg}\left(\mathrm{CF}_{3} \mathrm{SO}_{3}\right)_{2}$. It probably relates with the strong electronegativity of $\mathrm{TFSI}^{-}$ and $\mathrm{PF}_{6}{ }^{-}$anions, which may form a passive film with magnesium ions.

The ionic conductivity of $0.3 \mathrm{~mol} \mathrm{~L}^{-1} \mathrm{Mg}\left(\mathrm{CF}_{3} \mathrm{SO}_{3}\right)_{2}$ dissolving in the ILs with or without THF is summarized in Table 2 . The dissolution of $\mathrm{Mg}\left(\mathrm{CF}_{3} \mathrm{SO}_{3}\right)_{2}$ in ILs gives slightly lower conductivity than ILs. Furthermore, the conductivity of the solutions significantly increases after adding THF because the small molecule organic ether solvent reduces the viscosity of the ILs. High volatility of THF solvent can also be partly suppressed by mixing the nonvolatile ILs due to so-called "dilution effect." However, excess THF cannot be added considering the solubility of $\mathrm{Mg}\left(\mathrm{CF}_{3} \mathrm{SO}_{3}\right)_{2}$ in THF.

Figure 2 shows FTIR spectra (transmittance mode) of $\mathrm{BMImBF}_{4}, \mathrm{BMImBF}_{4}+\mathrm{THF}$ (with $3: 1$ volume ratio), $0.3 \mathrm{~mol} \mathrm{~L}^{-1} \quad \mathrm{Mg}\left(\mathrm{CF}_{3} \mathrm{SO}_{3}\right)_{2} / \mathrm{BMImBF}_{4}$, and $0.3 \mathrm{~mol} \mathrm{~L}^{-1}$ $\mathrm{Mg}\left(\mathrm{CF}_{3} \mathrm{SO}_{3}\right)_{2} / \mathrm{BMImBF}_{4}+\mathrm{THF}(3: 1)$. The peaks in the range of $3600-3300 \mathrm{~cm}^{-1}$ can be attributed to $\nu_{\mathrm{O}-\mathrm{H}}$ vibration from trace $\mathrm{H}_{2} \mathrm{O}$. $2840-3000 \mathrm{~cm}^{-1}$ and $1365-1470 \mathrm{~cm}^{-1}$ belong to $v_{\mathrm{C}-\mathrm{H}}$ and $\delta_{\mathrm{C}-\mathrm{H}}$ vibration modes of imidazolium cation, respectively. Those around $3100 \mathrm{~cm}^{-1}$ and $1630 \mathrm{~cm}^{-1}$ are related to $v_{\mathrm{C}-\mathrm{H}}$ and $\delta_{\mathrm{C}=\mathrm{C}}$ vibration mode of imidazolium ring, respectively. $1574 \mathrm{~cm}^{-1}$ can be attributed to the vibration of imidazolium ring, and the peaks between $1250 \mathrm{~cm}^{-1}$ and $1360 \mathrm{~cm}^{-1}$ belong to $\nu_{\mathrm{C}-\mathrm{N}}$ vibration. The peak of $750 \mathrm{~cm}^{-1}$ is related to the $\mathrm{C}-\mathrm{H}$ plane swing vibration and $1170 \mathrm{~cm}^{-1}$ to $\nu_{\mathrm{C}-\mathrm{C}}$ framework vibration. $840 \mathrm{~cm}^{-1}$ belongs to $\mathrm{H}-\mathrm{C}=\mathrm{C}-\mathrm{H}$ nonplanar angle vibration and $500-$ $650 \mathrm{~cm}^{-1}$ to far-infrared absorption frequency. The peaks of $521 \mathrm{~cm}^{-1}$ and $1059 \mathrm{~cm}^{-1}$ are the characteristic frequency of $\mathrm{BF}_{4}{ }^{-}$. Little difference appears between the spectra of $\mathrm{BMImBF}_{4}$ and $\mathrm{BMImBF}_{4}+\mathrm{THF}, \mathrm{Mg}\left(\mathrm{CF}_{3} \mathrm{SO}_{3}\right)_{2} / \mathrm{BMImBF}_{4}$,

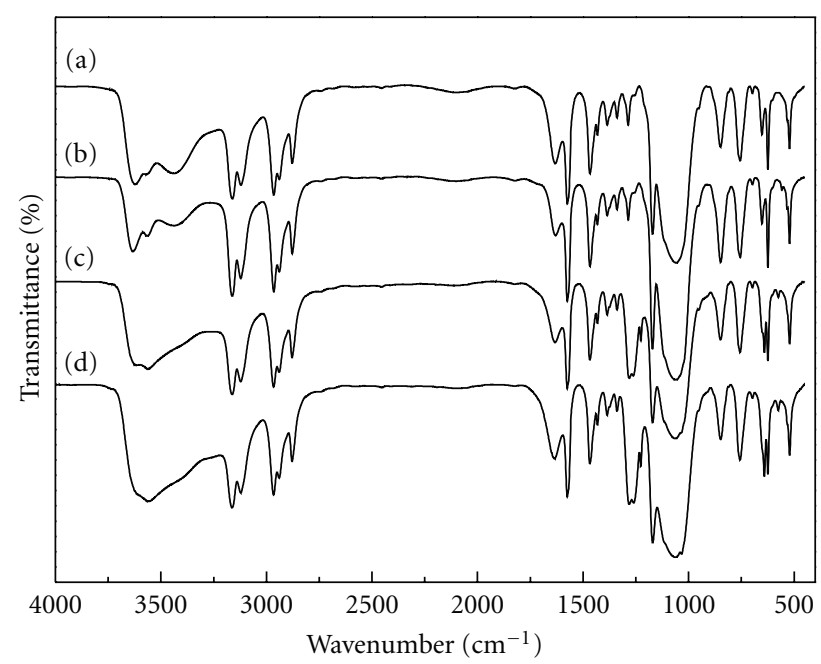

Figure 2: FTIR spectra of (a) $\mathrm{BMImBF}_{4}$, (b) $\mathrm{BMImBF}_{4}+$ THF (3:1), (c) $0.3 \mathrm{~mol} \mathrm{~L}^{-1} \mathrm{BMImBF}_{4} / \mathrm{Mg}\left(\mathrm{CF}_{3} \mathrm{SO}_{3}\right)_{2}$, and (d) $0.3 \mathrm{~mol} \mathrm{~L}^{-1} \mathrm{Mg}\left(\mathrm{CF}_{3} \mathrm{SO}_{3}\right)_{2} / \mathrm{BMImBF}_{4}+\operatorname{THF}(3: 1)$.

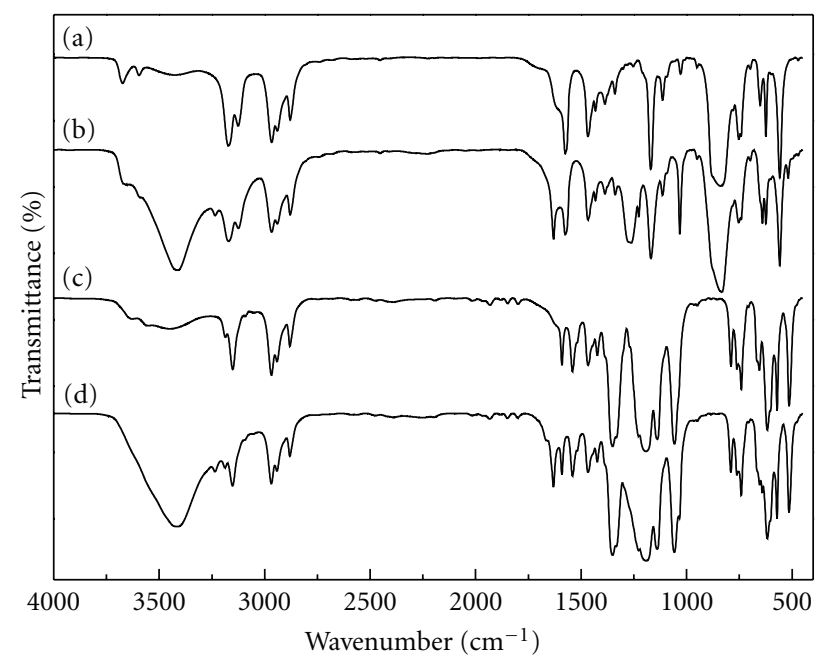

Figure 3: FTIR spectra of (a) $\mathrm{BMImPF}_{6}$, (b) $0.3 \mathrm{~mol} \mathrm{~L}-1$ $\mathrm{Mg}\left(\mathrm{CF}_{3} \mathrm{SO}_{3}\right)_{2} / \mathrm{BMImPF}_{6}$, (c) BMMImTFSI, and (d) $0.3 \mathrm{~mol} \mathrm{~L}^{-1}$ $\mathrm{Mg}\left(\mathrm{CF}_{3} \mathrm{SO}_{3}\right)_{2} / \mathrm{BMMImTFSI}$.

and $\mathrm{Mg}\left(\mathrm{CF}_{3} \mathrm{SO}_{3}\right)_{2} / \mathrm{BMImBF}_{4}+$ THF. It is suggested that the addition of a certain amount of THF has little impact on chemical constitutions of the solutions. After adding of a certain amount of $\mathrm{Mg}\left(\mathrm{CF}_{3} \mathrm{SO}_{3}\right)_{2}$, no characteristic peaks of $\mathrm{CF}_{3} \mathrm{SO}_{3}{ }^{-}$appear, and the characteristic peak of $\mathrm{BF}_{4}{ }^{-}$at 


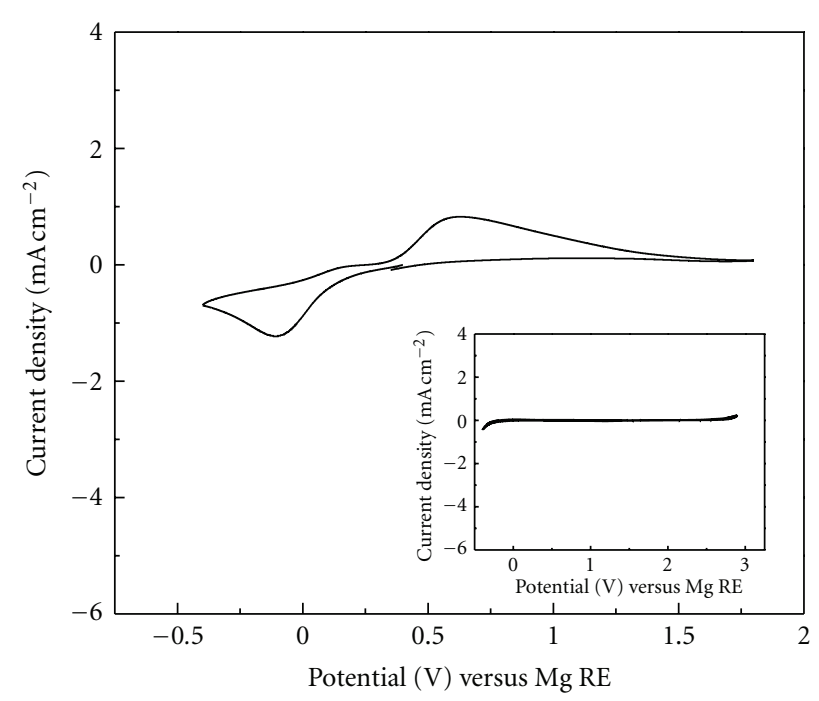

(a)

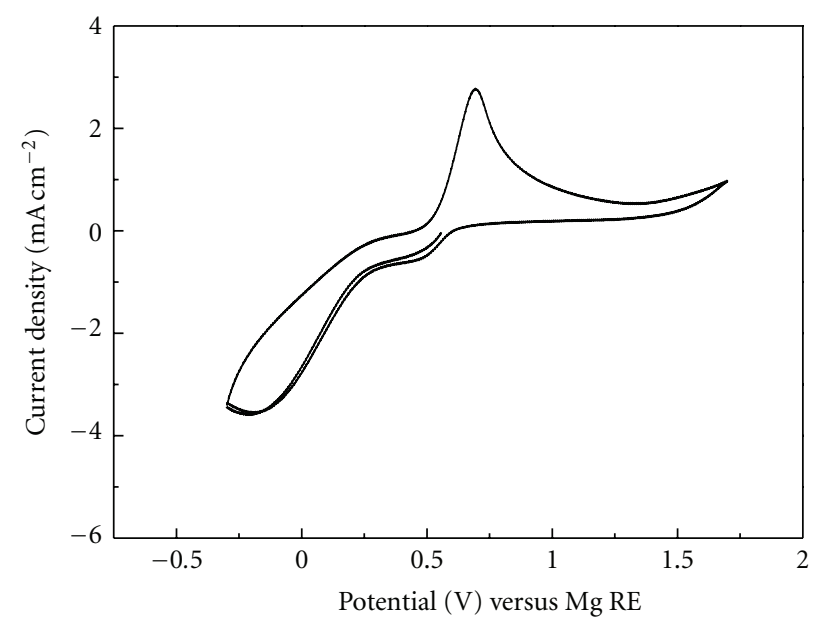

(c)

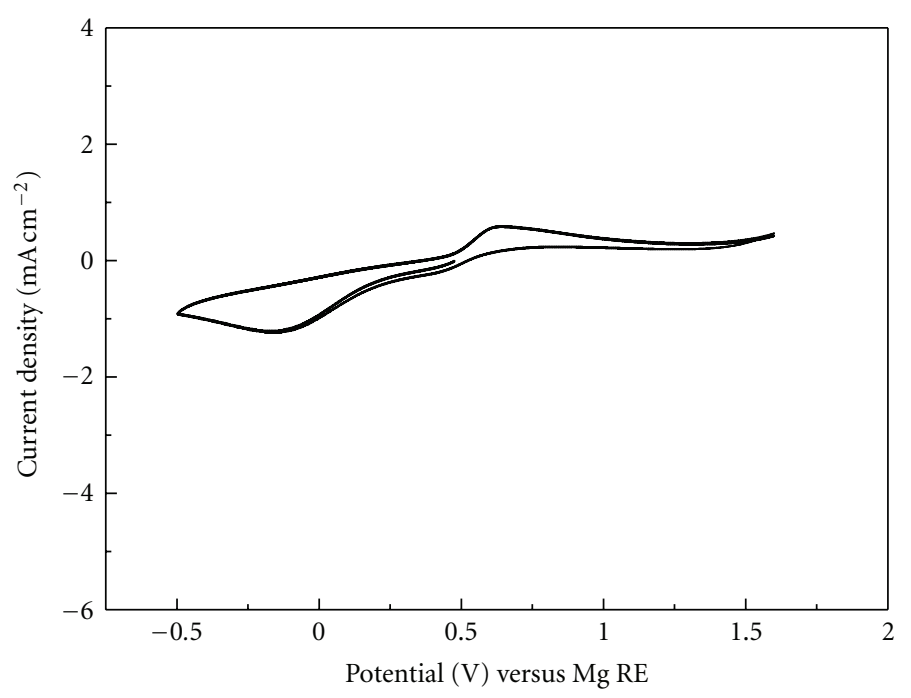

(b)

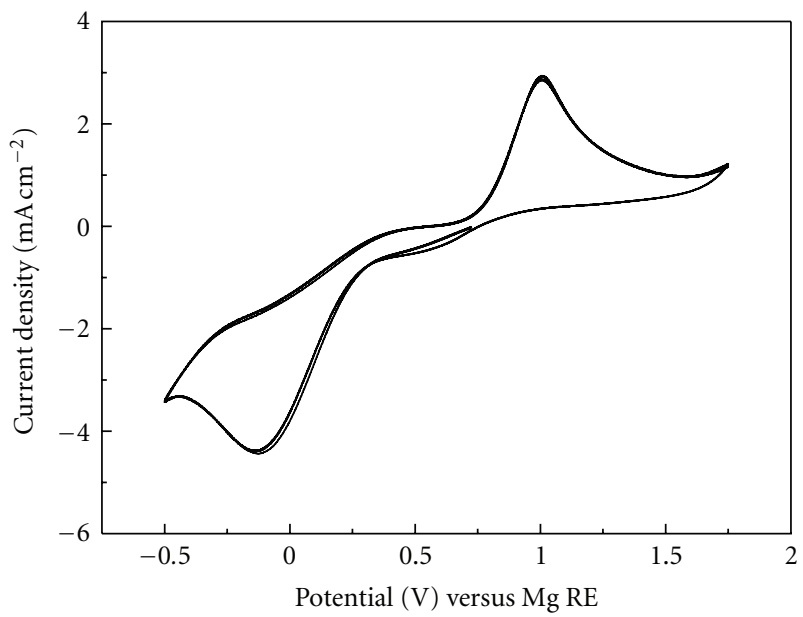

(d)

FIgURe 4: Typical cyclic voltammograms of $\mathrm{Mg}$ deposition-dissolution on Pt disk electrode from (a) $\left.0.3 \mathrm{~mol} \mathrm{~L}-1 \mathrm{Mg}^{-1} \mathrm{CF}_{3} \mathrm{SO}_{3}\right)_{2} / \mathrm{BMImBF}_{4}$, inset is the $\mathrm{CV}$ of $\mathrm{BMImBF}_{4}$, (b) $0.3 \mathrm{~mol} \mathrm{~L}^{-1} \mathrm{Mg}\left(\mathrm{CF}_{3} \mathrm{SO}_{3}\right)_{2} / \mathrm{BMImBF}_{4}+\mathrm{THF}(6: 1)$, (c) $0.3 \mathrm{~mol} \mathrm{~L}-1 \mathrm{Mg}\left(\mathrm{CF}_{3} \mathrm{SO}_{3}\right)_{2} / \mathrm{BMImBF}_{4}+\mathrm{THF}(3: 1)$, and (d) $0.3 \mathrm{~mol} \mathrm{~L}^{-1} \mathrm{Mg}\left(\mathrm{CF}_{3} \mathrm{SO}_{3}\right)_{2} / \mathrm{BMImBF}_{4}+\mathrm{THF}(1: 1)$. The scanning rate was $50 \mathrm{mV} \mathrm{s}^{-1}$.

$1059 \mathrm{~cm}^{-1}$ and the peak of $\nu_{\mathrm{C}-\mathrm{N}}$ vibration at $1280 \mathrm{~cm}^{-1}$ become double peaks, and a new peak at $1226 \mathrm{~cm}^{-1}$ is found. It is suggested that some complex reaction takes place between $\mathrm{Mg}\left(\mathrm{CF}_{3} \mathrm{SO}_{3}\right)_{2}$ and $\mathrm{BMImBF}_{4}$, which may restrain the formation of passive film, which is favorable for the reversible deposition-dissolution of magnesium.

Figure 3 shows FTIR spectra of $\mathrm{BMImPF}_{6}, 0.3 \mathrm{~mol} \mathrm{~L}^{-1}$ $\mathrm{Mg}\left(\mathrm{CF}_{3} \mathrm{SO}_{3}\right)_{2} / \mathrm{BMImPF}_{6}, \mathrm{BMMImTFSI}$, and $0.3 \mathrm{~mol} \mathrm{~L}^{-1}$ $\mathrm{Mg}\left(\mathrm{CF}_{3} \mathrm{SO}_{3}\right)_{2} / \mathrm{BMMImTFSI}$. The peak of $830 \mathrm{~cm}^{-1}$ belongs to the characteristic frequency of $\mathrm{PF}_{6}{ }^{-}$shown in Figures 3(a) and $3(\mathrm{~b})$, respectively. In Figures $3(\mathrm{c})$ and $3(\mathrm{~d}), 1350 \mathrm{~cm}^{-1}$ and $1192 \mathrm{~cm}^{-1}$ can be attributed to the characteristic peaks of $-\mathrm{CF}_{3}$ and $-\mathrm{SO}_{3}$, respectively. The peaks of $3496 \mathrm{~cm}^{-1}$, $1669 \mathrm{~cm}^{-1}$, and $1253 \mathrm{~cm}^{-1}$ are related to $\mathrm{CF}_{3} \mathrm{SO}_{3}{ }^{-}$. After adding $\mathrm{Mg}\left(\mathrm{CF}_{3} \mathrm{SO}_{3}\right)_{2}$, the characteristic peaks of $\mathrm{PF}_{6}{ }^{-}$and $\mathrm{CF}_{3} \mathrm{SO}_{3}{ }^{-}$remain (shown in Figures 3(a) and 3(b)). It is suggested that $\mathrm{Mg}^{2+}$ is not involved in the complex reaction because the strong electronegativity of $\mathrm{PF}_{6}{ }^{-}$may destroy the reaction. Similar phenomenons appear in ILs containing TFSI $^{-}$anions, as shown in Figures 3(c) and 3(d). It can be supposed that the passive film may take place in both of systems and no reversible magnesium deposition-dissolution appears.

We examined the reversible deposition-dissolution be havior of magnesium in $\mathrm{Mg}\left(\mathrm{CF}_{3} \mathrm{SO}_{3}\right)_{2} / \mathrm{BMImBF}_{4}$ solution and the impact of different THF volume ratio on the electrochemical performance. Figure 4 compares the cyclic voltammograms $(\mathrm{CVs})$ on platinum disk electrode from $\mathrm{BMImBF}_{4}, \quad 0.3 \mathrm{~mol} \mathrm{~L}^{-1} \mathrm{Mg}\left(\mathrm{CF}_{3} \mathrm{SO}_{3}\right)_{2} / \mathrm{BMImBF}_{4}$, $0.3 \mathrm{~mol} \mathrm{~L}^{-1} \mathrm{Mg}\left(\mathrm{CF}_{3} \mathrm{SO}_{3}\right)_{2} / \mathrm{BMImBF}_{4}+$ THF $(6: 1)$, $0.3 \mathrm{~mol} \mathrm{~L}^{-1} \mathrm{Mg}\left(\mathrm{CF}_{3} \mathrm{SO}_{3}\right)_{2} / \mathrm{BMImBF}_{4}+\operatorname{THF}(3: 1)$, and $0.3 \mathrm{~mol} \mathrm{~L}^{-1} \mathrm{Mg}\left(\mathrm{CF}_{3} \mathrm{SO}_{3}\right)_{2} / \mathrm{BMImBF}_{4}+\mathrm{THF}(1: 1)$ at $50 \mathrm{mV} \mathrm{s}^{-1}$. Compared to pure $\mathrm{BMImBF}_{4}$ (inset of Figure 4(a)), a redox wave at $-0.2 \mathrm{~V}$ and $0.6 \sim 1.0 \mathrm{~V}$ 


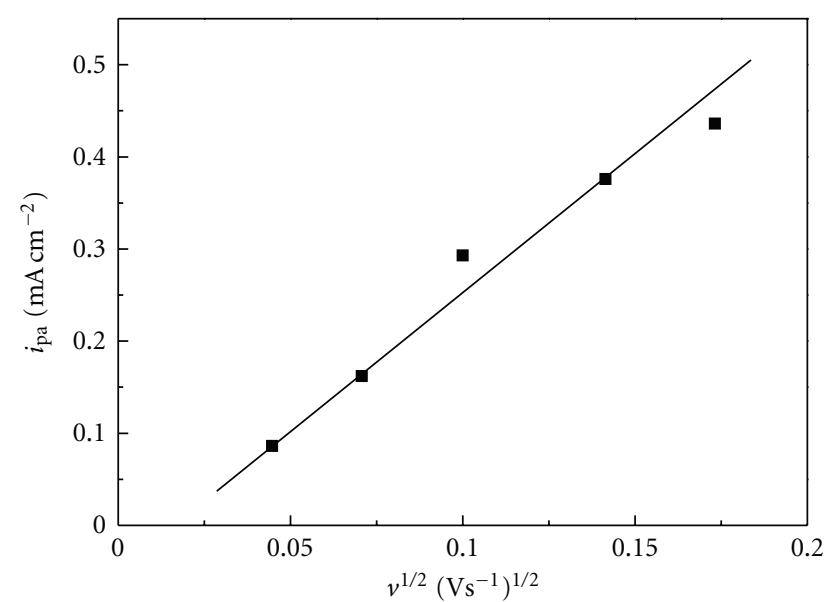

FIGURE 5: A plot of the anodic peak currents against square root of the scan rates for the striping of $\mathrm{Mg}$ on platinum disk electrode from $0.3 \mathrm{~mol} \mathrm{~L}^{-1} \mathrm{Mg}\left(\mathrm{CF}_{3} \mathrm{SO}_{3}\right)_{2} / \mathrm{BMImBF}_{4}+\operatorname{THF}(6: 1)$.

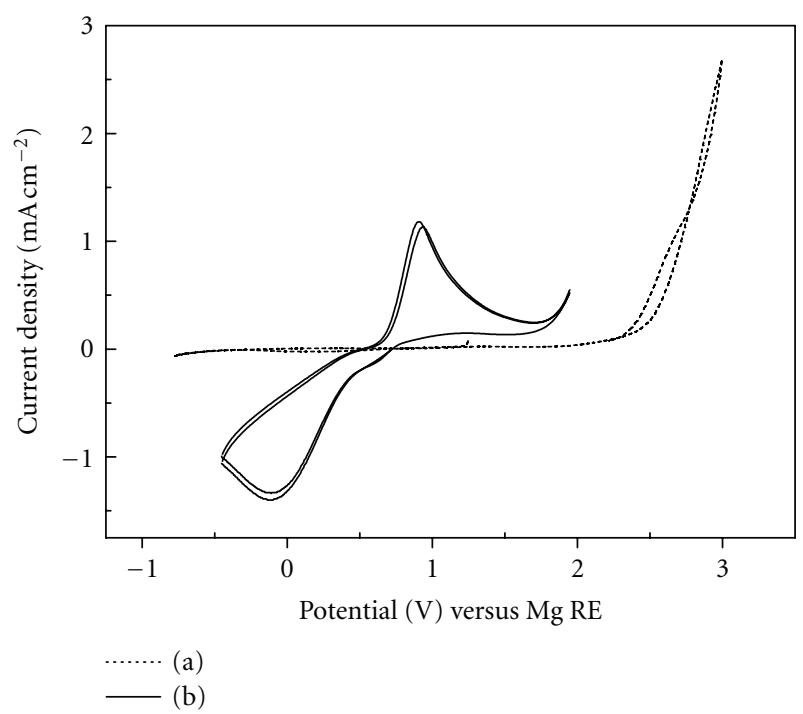

Figure 6: Typical cyclic voltammograms of $\mathrm{Mg}$ depositiondissolution on Pt disk electrode from (a) $\mathrm{BMMImBF}_{4}+\mathrm{THF}$ (3:1), (b) $0.3 \mathrm{~mol} \mathrm{~L}^{-1} \mathrm{Mg}\left(\mathrm{CF}_{3} \mathrm{SO}_{3}\right)_{2} / \mathrm{BMMImBF}_{4}+\mathrm{THF}(3: 1)$. The scanning rate was $50 \mathrm{mV} \mathrm{s}^{-1}$.

versus $\mathrm{Mg}$ appears in $0.3 \mathrm{~mol} \mathrm{~L}^{-1} \mathrm{Mg}\left(\mathrm{CF}_{3} \mathrm{SO}_{3}\right)_{2} / \mathrm{BMImBF}_{4}$ (Figure 4(a)), which may correspond to the couple of cathodic deposition and anodic dissolution of Mg. The peak current density is low due to a low conductivity of the solution. Adding THF can improve the conductivity, and the peak current density increases with the increase of THF amount (Figures 4(b), 4(c), and 4(d)). However, the overpotential between reduction and oxidation peaks becomes larger when the ratio of $\mathrm{BMImBF}_{4}$ and THF reaches to $1: 1$ (Figure $4(\mathrm{~d})$ ). Because of the lower solubility of $\mathrm{Mg}\left(\mathrm{CF}_{3} \mathrm{SO}_{3}\right)_{2}$ in THF, excess THF may affect the solubility of $\mathrm{Mg}\left(\mathrm{CF}_{3} \mathrm{SO}_{3}\right)_{2}$ in the ILs and the electrochemical performance of the solution. The plot of the anodic peak currents versus square root of the scan rates on platinum

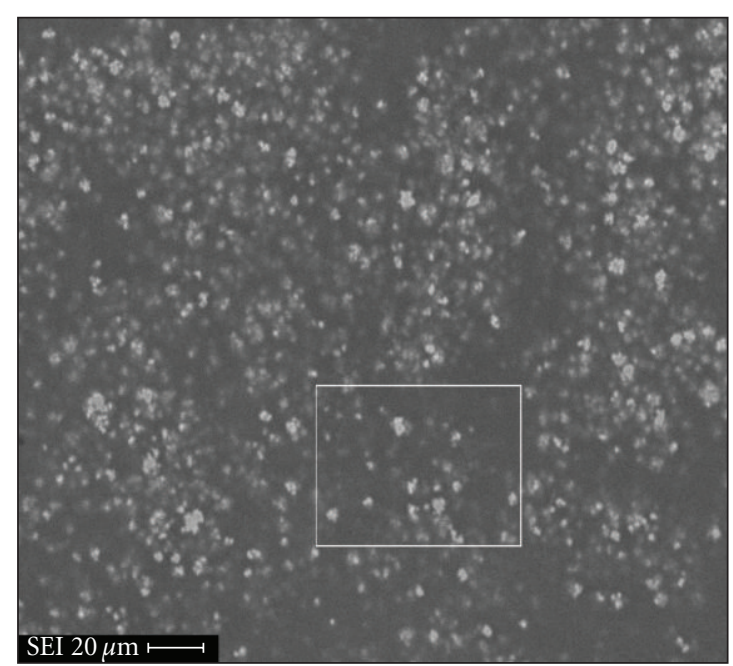

(a)

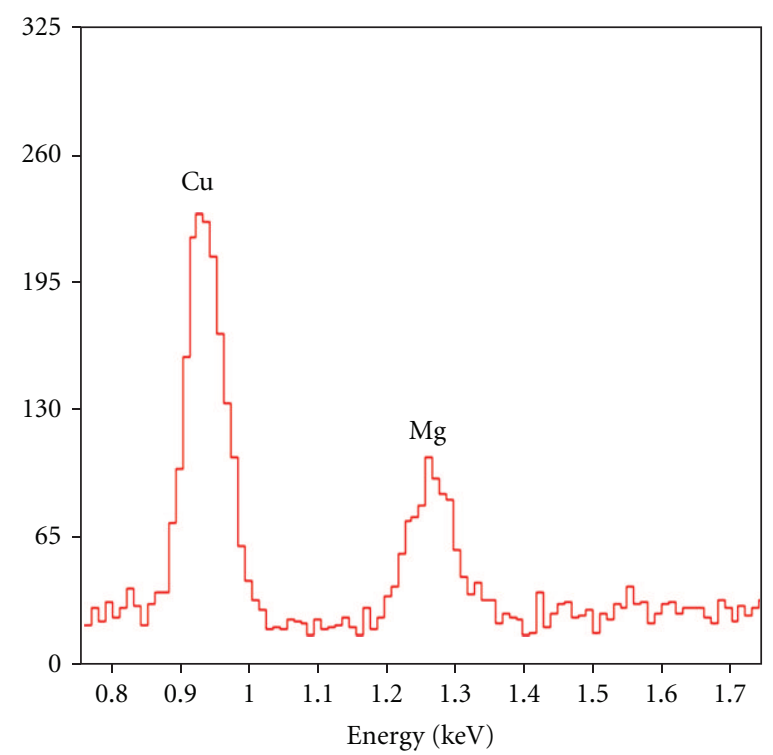

(b)

FIGURE 7: SEM image of magnesium deposit and corresponding EDS result on copper substrate from $0.3 \mathrm{~mol} \mathrm{~L}^{-1} \mathrm{Mg}\left(\mathrm{CF}_{3} \mathrm{SO}_{3}\right)_{2}$ / $\mathrm{BMImBF}_{4}+\mathrm{THF}(3: 1)$ solution. The charge amount is $1.8 \mathrm{C} \mathrm{cm}^{-2}$.

disk electrode from $0.3 \mathrm{~mol} \mathrm{~L}^{-1} \mathrm{Mg}\left(\mathrm{CF}_{3} \mathrm{SO}_{3}\right)_{2} / \mathrm{BMImBF}_{4}$ $+\operatorname{THF}(6: 1)$ is shown in Figure 5. The linear plot proves that the mass-transport process is most likely diffusion of electroactive species from the electrolyte to the electrode interface.

As shown in Table 1, the stability of imidazolium cation of $\mathrm{BMImBF}_{4}$ can be improved when active $\mathrm{H}$ in the cation is substituted by methyl. Figure 6 shows typical cyclic voltammograms on Pt disk electrode from $\mathrm{BMMImBF}_{4}+$ THF (3:1) and $0.3 \mathrm{~mol} \mathrm{~L}^{-1} \mathrm{Mg}\left(\mathrm{CF}_{3} \mathrm{SO}_{3}\right)_{2} / \mathrm{BMMImBF}_{4}+$ THF $(3: 1)$ at $50 \mathrm{mV} \mathrm{s}^{-1}$. The reduction potential of blank solution of $\mathrm{BMMImBF}_{4}+\mathrm{THF}$ arrives to $-0.8 \mathrm{~V}$ versus $\mathrm{Mg}$ and oxidation potential to $2.5 \mathrm{~V}$ versus $\mathrm{Mg}$. The addition of $\mathrm{Mg}\left(\mathrm{CF}_{3} \mathrm{SO}_{3}\right)_{2}$ causes the appearance of a reduction 


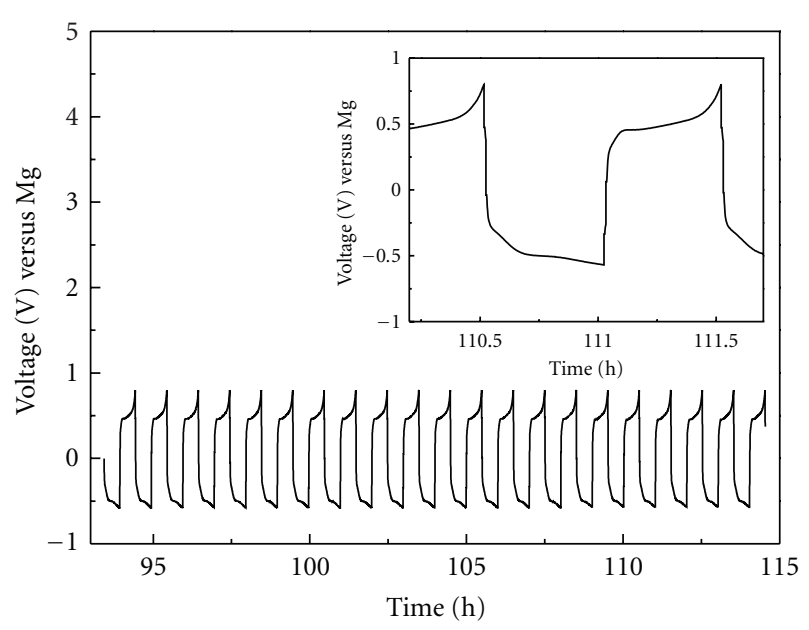

(a)

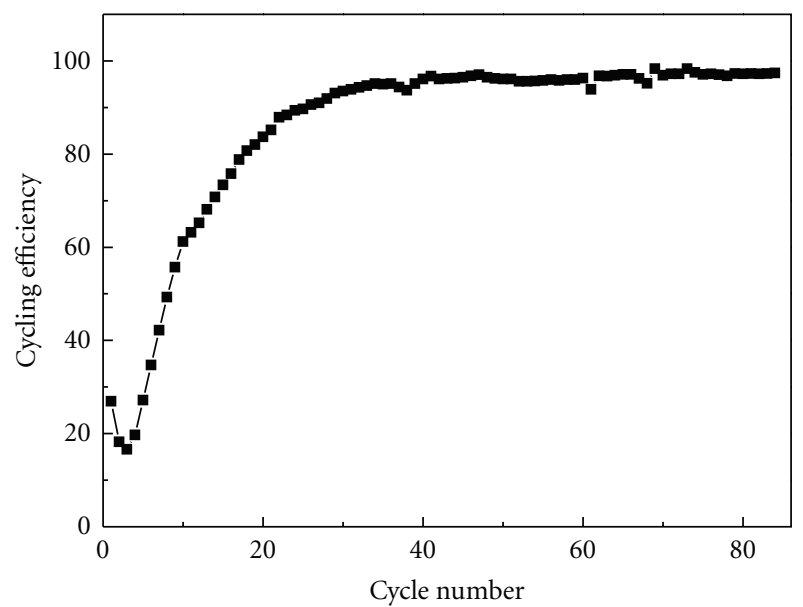

(b)

Figure 8: Typical galvanostatic cycling curves (a) Inset shows one of the cycle curves, and cycling efficiencies (b) for Mg depositiondissolution on $\mathrm{Cu}$ substrate in $0.3 \mathrm{~mol} \mathrm{~L}-1 \mathrm{Mg}\left(\mathrm{CF}_{3} \mathrm{SO}_{3}\right)_{2} / \mathrm{BMImBF}_{4}+\mathrm{THF}(3: 1)$. The counter electrode is $\mathrm{Mg}$ sheet.

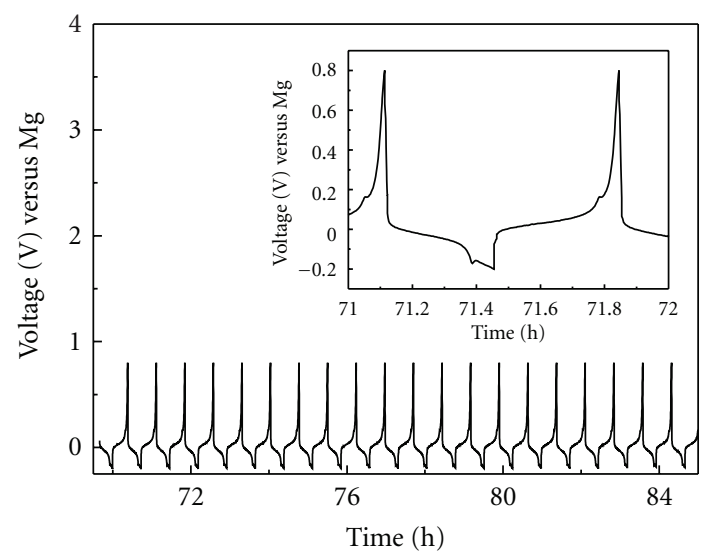

FIgURE 9: Typical galvanostatic cycling curves for $\mathrm{Mg}$ depositiondissolution on $\mathrm{Cu}$ substrate in $0.3 \mathrm{~mol} \mathrm{~L}^{-1} \mathrm{Mg}\left(\mathrm{CF}_{3} \mathrm{SO}_{3}\right)_{2} / \mathrm{BMImBF}_{4}$ + THF $(3: 1)$ inset shows one of the cycle curves. The counter electrode is magnesium powder electrode.

process at $-0.11 \mathrm{~V}$ and a oxidation process at $0.91 \mathrm{~V}$, with current significantly higher than the background current in this potential range. Though the reversibility of $\mathrm{Mg}^{2+}$ in $\mathrm{BMMImBF}_{4}$ is improved compared to $\mathrm{BMImBF}_{4}$, the peak current density is smaller due to the lower conductivity.

The surface morphology and composition of the electrodeposited layer was investigated by means of scanning electron microscope equipped with an energy dispersive Xray spectroscopy. Figure 7 shows the SEM image and corresponding EDS result of the deposit on copper substrate from $0.3 \mathrm{~mol} \mathrm{~L}^{-1} \mathrm{Mg}\left(\mathrm{CF}_{3} \mathrm{SO}_{3}\right)_{2} / \mathrm{BMImBF}_{4}+\mathrm{THF}(3: 1)$ solution, the deposited charge amount is $1.8 \mathrm{C} \mathrm{cm}^{-2}$. Although the deposit is sparse and uneven, micrometric size crystals can be observed. EDS analysis shows that the deposit contains magnesium, in addition to copper that resulted from the substrate. In order to know whether the deposit contains crystalline magnesium or not, XRD analysis was performed. However, the layer is too thin to produce good XRD pattern.

Figure 8 presents typical magnesium deposition-dissolution cycles on $\mathrm{Cu}$ substrate in $0.3 \mathrm{~mol} \mathrm{~L}^{-1} \mathrm{Mg}\left(\mathrm{CF}_{3} \mathrm{SO}_{3}\right)_{2} /$ $\mathrm{BMImBF}_{4}+$ THF $(3: 1)$ and the cycling efficiencies (calculated according to the ratio of the charge amount of magnesium dissolution to that of magnesium deposition) during initial 85 cycles. The counter electrode is $\mathrm{Mg}$ sheet. As shown in the Figure 8(a), the deposition potential of $\mathrm{Mg}$ on $\mathrm{Cu}$ substrate is about $-0.5 \mathrm{~V}$ and the corresponding dissolution potential is $0.5 \mathrm{~V}$. The cycling efficiencies during initial 20 cycles are low because of the complex adsorption and diffusion of electrolyte. After 20 cycles, the cycling efficiencies can reach about $96 \%$. When $\mathrm{Mg}$ sheet electrode is replaced with $\mathrm{Mg}$ powder electrode, the potentials of deposition and dissolution are significantly reduced (shown in Figure 9). It is suggested that the increase of the electrode surface area has a marked effect on decreasing the interfacial resistance and suppressing the potential polarization. This is mostly attributed to the porous characters and stable and homogeneous interface of the powder electrode $[34,35]$.

\section{Conclusions}

Several imidazolium-based ILs containing $0.3 \mathrm{~mol} \mathrm{~L}^{-1}$ $\mathrm{Mg}\left(\mathrm{CF}_{3} \mathrm{SO}_{3}\right)_{2}$ for electrochemical magnesium deposition and dissolution were systematically studied. The chemical structure of imidazolium cations has a remarkable impact on the ionic conductivity and the electrochemical window of the solutions. After adding of a certain amount of THF, the conductivity of the solution, the performance for $\mathrm{Mg}$ deposition-dissolution can be improved. Replacing $\mathrm{Mg}$ sheet electrode with $\mathrm{Mg}$ powder electrode, the potential polarization of deposition-dissolution process is decreased. 


\section{Acknowledgment}

This work is supported by the National Nature Science Foundation of China (Project no. 20603022, 20973112).

\section{References}

[1] M. Armand and J. M. Tarascon, "Building better batteries," Nature, vol. 451, no. 7179, pp. 652-657, 2008.

[2] T. D. Gregory, R. J. Hoffman, and R. C. Winterton, "Nonaqueous electrochemistry of magnesium. Applications to energy storage," Journal of the Electrochemical Society, vol. 137, no. 3, pp. 775-780, 1990.

[3] P. Novák, R. Imhof, and O. Haas, "Magnesium insertion electrodes for rechargeable nonaqueous batteries-a competitive alternative to lithium?" Electrochimica Acta, vol. 45, no. 1, pp. 351-367, 1999.

[4] D. Aurbach, Z. Lu, A. Schechter et al., "Prototype systems for rechargeable magnesium batteries," Nature, vol. 407, no. 6805, pp. 724-727, 2000.

[5] D. Aurbach, A. Schechter, M. Moshkovich, and Y. Cohen, "On the mechanisms of reversible magnesium deposition processes," Journal of the Electrochemical Society, vol. 148, no. 9, pp. A1004-A1014, 2001.

[6] Y. Viestfrid, M. D. Levi, Y. Gofer, and D. Aurbach, "Microelectrode studies of reversible $\mathrm{Mg}$ deposition in THF solutions containing complexes of alkylaluminum chlorides and dialkylmagnesium," Journal of Electroanalytical Chemistry, vol. 576, no. 2, pp. 183-195, 2005.

[7] Z. Lu, A. Schechter, M. Moshkovich, and D. Aurbach, "On the electrochemical behavior of magnesium electrodes in polar aprotic electrolyte solutions," Journal of Electroanalytical Chemistry, vol. 466, no. 2, pp. 203-217, 1999.

[8] C. Liebenow, "Reversibility of electrochemical magnesium deposition from Grignard solutions," Journal of Applied Electrochemistry, vol. 27, no. 2, pp. 221-225, 1997.

[9] D. Aurbach, M. Moshkovich, A. Schechter, and R. Turgeman, "Magnesium deposition and dissolution processes in ethereal Grignard salt solutions using simultaneous EQCM-EIS and in situ FTIR spectroscopy," Electrochemical and Solid-State Letters, vol. 3, no. 1, pp. 31-34, 2000.

[10] Y. S. Guo, J. Yang, Y. Nuli, and J. Wang, "Study of electronic effect of Grignard reagents on their electrochemical behavior," Electrochemistry Communications, vol. 12, no. 12, pp. 16711673, 2010.

[11] C. Liebenow, Z. Yang, and P. Lobitz, "The electrodeposition of magnesium using solutions of organomagnesium halides, amidomagnesium halides and magnesium organoborates," Electrochemistry Communications, vol. 2, no. 9, pp. 641-645, 2000.

[12] Q. S. Zhao, Y. N. Nuli, Y. S. Guo, J. Yang, and J. L. Wang, "Reversibility of electrochemical magnesium deposition from tetrahydrofuran solutions containing pyrrolidinyl magnesium halide," Electrochimica Acta, vol. 56, no. 18, pp. 6530-6535, 2011.

[13] D. Aurbach, H. Gizbar, A. Schechter et al., "Electrolyte solutions for rechargeable magnesium batteries based on organomagnesium chloroaluminate complexes," Journal of the Electrochemical Society, vol. 149, no. 2, pp. A115-A121, 2002.

[14] Y. Gofer, O. Chusid, H. Gizbar et al., "Improved electrolyte solutions for rechargeable magnesium batteries," Electrochemical and Solid-State Letters, vol. 9, no. 5, pp. A257-A260, 2006.
[15] O. Mizrahi, N. Amir, E. Pollak et al., "Electrolyte solutions with a wide electrochemical window for rechargeable magnesium batteries," Journal of the Electrochemical Society, vol. 155, no. 2, pp. A103-A109, 2008.

[16] M. A. P. Martins, C. P. Frizzo, D. N. Moreira, N. Zanatta, and H. G. Bonacorso, "Ionic liquids in heterocyclic synthesis," Chemical Reviews, vol. 108, no. 6, pp. 2015-2050, 2008.

[17] J. P. Hallett and T. Welton, "Room-temperature ionic liquids: solvents for synthesis and catalysis. 2," Chemical Reviews, vol. 111, no. 5, pp. 3508-3576, 2011.

[18] X. X. Han and D. W. Armstrong, "Ionic liquids in separations," Accounts of Chemical Research, vol. 40, no. 11, pp. 1079-1086, 2007.

[19] J. E. F. Weaver, D. Breadner, F. Deng, B. Ramjee, P. J. Ragogna, and R. W. Murray, "Electrochemistry of ferrocenefunctionalized phosphonium ionic liquids," Journal of Physical Chemistry C, vol. 115, no. 39, pp. 19379-19385, 2011.

[20] R. D. Rogers and K. R. Seddon, "Ionic liquids—solvents of the future?" Science, vol. 302, no. 5646, pp. 792-793, 2003.

[21] K. Tsunashima and M. Sugiya, "Electrochemical behavior of lithium in room-temperature phosphonium ionic liquids as lithium battery electrolytes," Electrochemical and Solid-State Letters, vol. 11, no. 2, pp. A17-A19, 2008.

[22] D. M. Tigelaar, A. E. Palker, M. A. B. Meador, and W. R. Bennett, "Synthesis and compatibility of ionic liquid containing rod-coil polyimide gel electrolytes with lithium metal electrodes," Journal of the Electrochemical Society, vol. 155, no. 10, pp. A768-A774, 2008.

[23] V. Etacheri, R. Marom, R. Elazari, G. Salitra, and D. Aurbach, "Challenges in the development of advanced Li-ion batteries: a review," Energy and Environmental Science, vol. 4, no. 9, pp. 3243-3262, 2011.

[24] A. Lewandowski and A. Świderska-Mocek, "Ionic liquids as electrolytes for Li-ion batteries-An overview of electrochemical studies," Journal of Power Sources, vol. 194, no. 2, pp. 601609, 2009.

[25] M. Galiński, A. Lewandowski, and I. Stepniak, "Ionic liquids as electrolytes," Electrochimica Acta, vol. 51, no. 26, pp. 5567$5580,2006$.

[26] Y. NuLi, J. Yang, and R. Wu, "Reversible deposition and dissolution of magnesium from $\mathrm{BMIMBF}_{4}$ ionic liquid," Electrochemistry Communications, vol. 7, no. 11, pp. 11051110, 2005.

[27] Y. NuLi, J. Yang, J. Wang, J. Xu, and P. Wang, “Electrochemical magnesium deposition and dissolution with high efficiency in ionic liquid," Electrochemical and Solid-State Letters, vol. 8, no. 11, pp. C166-C169, 2005.

[28] Y. NuLi, J. Yang, and P. Wang, "Electrodeposition of magnesium film from BMIMBF4 ionic liquid," Applied Surface Science, vol. 252, no. 23, pp. 8086-8090, 2006.

[29] P. Wang, Y. NuLi, J. Yang, and Z. Feng, "Mixed ionic liquids as electrolyte for reversible deposition and dissolution of magnesium," Surface and Coatings Technology, vol. 201, no. 6, pp. 3783-3787, 2006.

[30] G. T. Cheek, W. E. O’Grady, S. Z. El Abedin, E. M. Moustafa, and F. Endres, "Studies on the electrodeposition of magnesium in ionic liquids," Journal of the Electrochemical Society, vol. 155, no. 1, pp. D91-D95, 2008.

[31] N. Yoshimoto, M. Matsumoto, M. Egashia, and M. Morita, "Mixed electrolyte consisting of ethylmagnesiumbromide with ionic liquid for rechargeable magnesium electrode," Journal of Power Sources, vol. 195, no. 7, pp. 2096-2098, 2010.

[32] O. Shimamura, N. Yoshimoto, M. Matsumoto, M. Egashia, and M. Morita, "Electrochemical co-deposition of magnesium 
with lithium from quaternary ammonium-based ionic liquid," Journal of Power Sources, vol. 196, no. 3, pp. 1586-1588, 2011.

[33] T. Kakibe, N. Yoshimoto, M. Egashira, and M. Morita, "Optimization of cation structure of imidazolium-based ionic liquids as ionic solvents for rechargeable magnesium batteries," Electrochemistry Communications, vol. 12, no. 11, pp. 1630-1633, 2010.

[34] J. H. Chung, W. S. Kim, W. Y. Yoon, S. W. Min, and B. W. Cho, "Electrolyte loss and dimensional change of the negative electrode in Li powder secondary cell," Journal of Power Sources, vol. 163, no. 1, pp. 191-195, 2006.

[35] J. S. Kim, S. H. Baek, and W. Y. Yoon, "Electrochemical behavior of compacted lithium powder electrode in $\mathrm{Li} / \mathrm{V}_{2} \mathrm{O}_{5}$ rechargeable battery," Journal of the Electrochemical Society, vol. 157, no. 8, pp. A984-A987, 2010. 


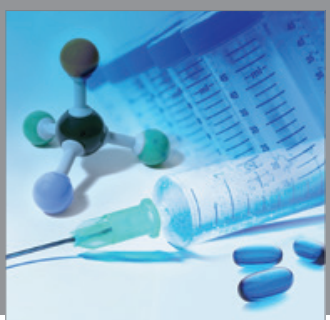

International Journal of

Medicinal Chemistry

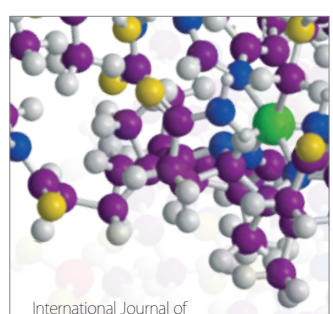

Carbohydrate Chemistry

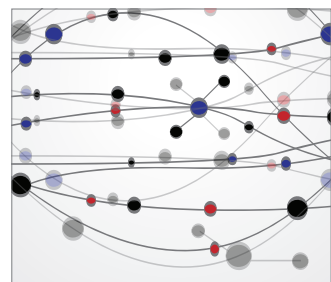

The Scientific World Journal
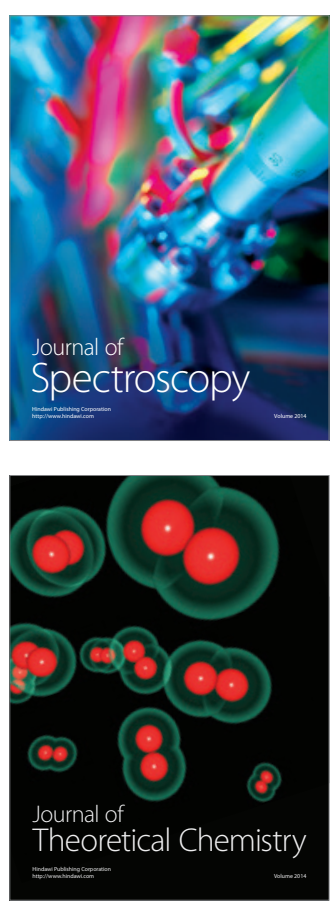
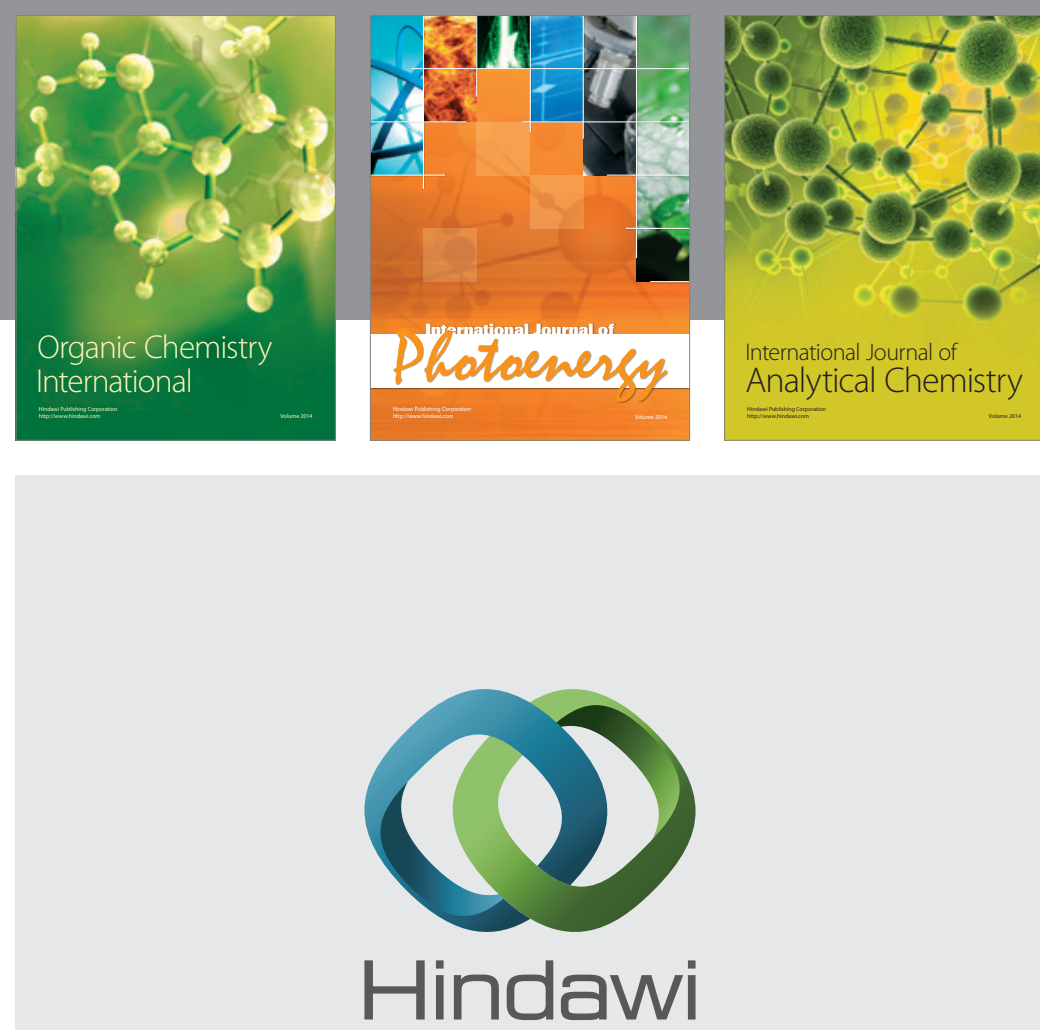

Submit your manuscripts at

http://www.hindawi.com
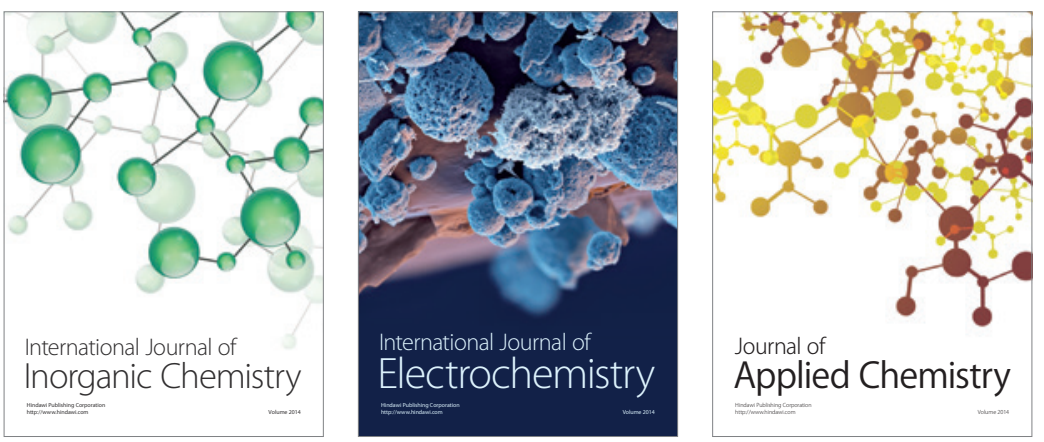

Journal of

Applied Chemistry
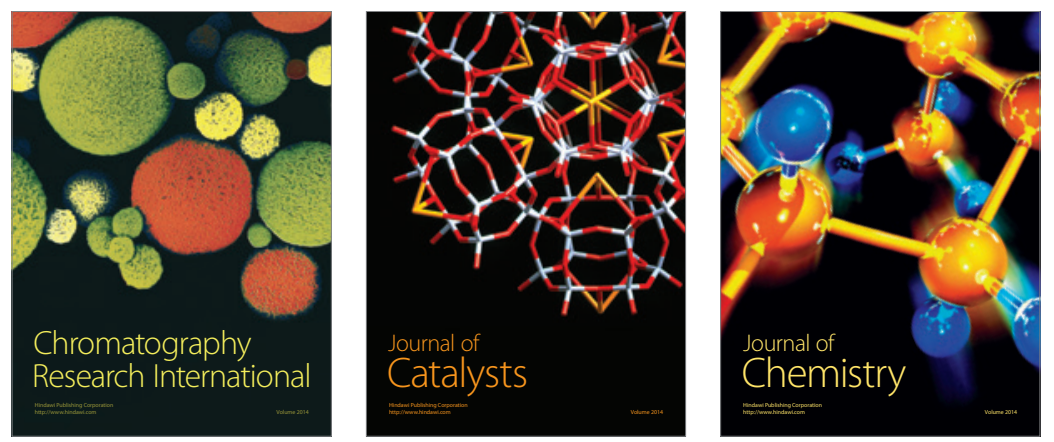
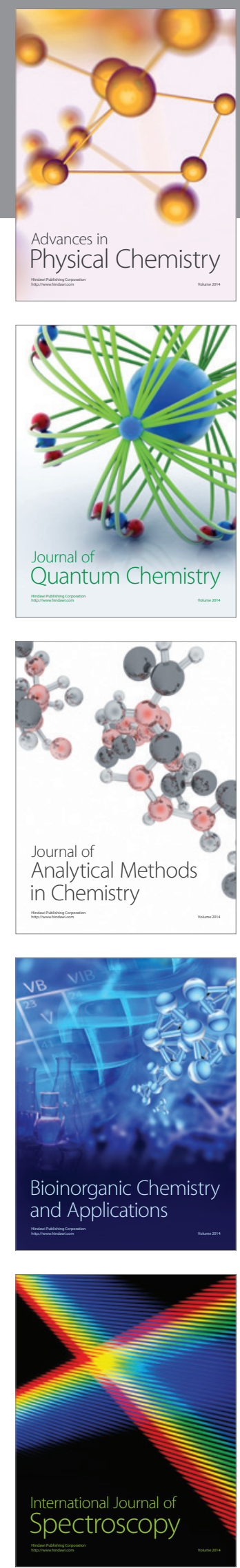